Acta vet. scand. 1973, 14, $410-420$.

From the Department of Surgery, College of Veterinary Science, Tirupati, Andhra Pradesh, India, and the Department of Inorganic Chemistry, Royal Veterinary and Agricultural University, Copenhagen, Denmark.

\title{
BOVINE UROLITHIASIS IN ANDHRA PRADESH
}

\author{
By
}

S. V. Rao and A. Unmack

RAO, S. V. and A. UNMACK: Bovine urolithiasis in Andhra Pradesh. Acta vet. scand. 1973, 1/4, 410-420. - Urinary calculi from three bulls, six bullocks and one male buffalo from the Guntur district were investigated. By chemical analysis only $\mathrm{CO}_{3}^{2}, \mathrm{Ca}^{2+}, \mathrm{Mg}^{2+}$, and a trace of $\mathrm{PO}_{4}^{3^{-}}$were found. X-ray analysis showed that all samples consisted of magnesian calcite with an atomic percentage of magnesium between 14.5 and 21.9. The size of the crystallites varied approx. from 200 to $400 \AA$ A.

urolithiasis; magnesian calcite; calculi.

Bovine urolithiasis is endemic in three regions of Andhra Pradesh (South-East India): Guntur and Krishna districts of Coastal Andhra, Cuddapah, Kurnool and Anantapur districts of Rayalaseema, and Nalgonda and Mahaboobnagar districts of the Telangana regions.

In spite of the encouraging results obtained by simple surgical treatment of urethral obstruction, with or without rupture of the bladder (Rao 1972), urolithiasis still remains a problem due to recurrence after the operation because cystic calculi again migrate into the urethra. Their removal by laparocystotomy is not easy and the results under field conditions are discouraging.

It has been attempted to dissolve urinary calculi in situ by flushing with appropriate solvents (Meyer 1925, 1927, 1929, Gehres \& Raymond 1951, Mudvaney 1959, 1960), but in order to choose the best solvent a correct knowledge of the composition of the calculi is essential. If calculi from the three regions are analysed and an exact knowledge of their composition is thus obtained, the possibility of preventing a recurrence after the 
operation by flushing can be considered. This idea prompted the first author to a study of the composition of the calculi.

In view of the extension of urolithiasis, the amount of analytical work done in India is relatively small. Ranganathan (1931a, b) from South India, Kataria \& Rao (1969) from Central India, and Sinha (1952), Mohanty (1963), Ranjhan et al. (1965), and Chakrabarti et al. (1970) from North India published the compositions of urinary stones from cattle and buffaloes. Their results are given in Table 1 . In the original papers the results were given on different scales -- as percentage of oxides, carbonates, and the elements themselves. In order to facilitate comparison, all results have been recalculated and given as per cent $\mathrm{Ca}, \mathrm{Mg}$, etc.

The results given by Ranganathan (1931a), by Sinha and by Mohanty (the latter later with more details by Ranjhan et al.) show that their samples have been carbonate stones. Although carbonate is not explicitly mentioned, the same probably applies to Kataria \& Rao's silica-free stones and to some of Chakrabarti et al.'s samples. The stone taken from a calf, described in Ranganathan's second paper (1931b), is of phosphatic type.

T a b l e 1. Older Indian results.

\begin{tabular}{|c|c|c|c|c|c|c|c|c|}
\hline Authors & $\% \mathrm{Ca}$ & $\% \mathbf{M g}$ & $\% \mathbf{P}$ & $\% \mathrm{~N}$ & $\% \mathrm{CO}_{2}$ & $\% \mathrm{H}_{2} \mathrm{O}$ & $\%$ ox.ac. & ur.ac. \\
\hline Ranganathan (1931a) ${ }^{1}$ & 31.46 & 2.92 & 0.39 & 0.37 & 39.07 & 3.10 & 0.7 & 0 \\
\hline Ranganathan (1931b) ${ }^{2}$ & 7.79 & 7.96 & 9.60 & 7.60 & 0 & 16.07 & & $\mathbf{0}$ \\
\hline Sinha $(1952)^{3}$ & 28.4 & 7.50 & 0.12 & & & & 0 & $\mathbf{0}$ \\
\hline $\left.\begin{array}{l}\text { Mohanty }(1963)^{4} \\
\text { Ranjhan et al. }(1965)^{5}\end{array}\right\}$ & 12.135 & 2.322 & 0.096 & & & & & \\
\hline Kataria \& Rao $(1969)^{6}$ & 32.0 & 0.63 & 1.46 & & & & & \\
\hline Chakrabarti et al. (1970)? & 26.9 & 5.2 & 1.85 & & & & & \\
\hline
\end{tabular}

1 Given as: $44.00 \% \mathrm{CaO} ; 4.84 \% \mathrm{MgO} ; 0.90 \% \mathrm{P}_{2} \mathrm{O}_{5} ; 0.6 \% \mathrm{C}_{2} \mathrm{O}_{3}$. Dried material.

2 Given as: $10.90 \% \mathrm{CaO} ; 12.05 \% \mathrm{MgO} ; 22.00 \% \mathrm{P}_{2} \mathrm{O}_{5}$. Dried material.

3 Given as: $71 \% \mathrm{CaCO}_{3} ; 26 \% \mathrm{MgCO}_{3} ; 3 \% \mathrm{Ca}_{3}\left(\mathrm{PO}_{4}\right)_{2}$. Probably undried material.

${ }^{4}$ and ${ }^{5}$ same analyses. ${ }^{4}$ gives only the average, ${ }^{5}$ also individual values. Say: carbonate reaction "heavy". Probably undried material.

- $44 \%$ of the samples investigated contained $\mathrm{Si}$. The values given here are average values for six Si-free samples. Probably undried material.

7 Average values for 24 samples of very varying composition. Probably undried. 
The only results for cattle stones from Andhra Pradesh were published about 40 years ago (Ranganathan, loc. cit.). It was therefore considered desirable to analyse again calculi from the different regions in Andhra Pradesh using modern physical methods. Guntur District was taken first.

\section{MATERIALS}

Calculi were collected from three bulls, six bullocks and one male buffalo. As it was considered possible that the calculi might consist of hydrous silica and as it is known that the formation of this type of concrement depends on the content of silica in the fodder (Whiting et al. 1958, Forman et al. 1958, 1959, Forman \& Sauer 1962, Connell et al. 1959), samples were also collected of the plants on which the cattle had been fed, as well as of the mud settling on the plants after floods, all from the same villages as the clinical cases. As it was found, however, that the calculi did not contain silica, but consisted of magnesian calcite, the fodder and the mud were not analysed.

T a ble 2. Origin and outer appearance of samples.

\begin{tabular}{|c|c|c|c|c|c|c|}
\hline \multicolumn{4}{|c|}{ Animal } & \multicolumn{3}{|c|}{ Description of samples } \\
\hline $\begin{array}{l}\text { sample } \\
\text { no. }\end{array}$ & type & $\begin{array}{c}\text { age } \\
\text { (years) }\end{array}$ & $\begin{array}{l}\text { weight } \\
\text { (lbs.) }\end{array}$ & number & $\begin{array}{l}\text { weight } \\
\text { (g) }\end{array}$ & $\begin{array}{l}\text { colour and special } \\
\text { features }\end{array}$ \\
\hline 1 & bullock & 9 & 1500 & 21 & $2.80^{* *}$ & $\begin{array}{l}\text { light grey to brownish } \\
\text { grey; lustre }\end{array}$ \\
\hline 2 & bullock & 12 & 1000 & 5 & $3.33^{* *}$ & as 1 , but less lustre \\
\hline 3 & bullock & 4 & 600 & $12^{*}$ & $2.14^{* *}$ & as 2 \\
\hline 4 & bullock & 8 & 800 & $>50$ & 3.49 & $\begin{array}{l}\text { yellowish; beautiful } \\
\text { lustre }\end{array}$ \\
\hline 5 & bull & 3 & 700 & 18 & 1.19 & light yellow; no lustre \\
\hline 6 & bull & $2 \frac{1}{2}$ & 500 & $>50$ & 2.43 & $\begin{array}{l}\text { light yellow; lustre; } \\
\text { small black spots }\end{array}$ \\
\hline 7 & bullock & 14 & 900 & $>50$ & 4.36 & $\begin{array}{l}\text { as } 6 \text {, but more } \\
\text { contaminated }\end{array}$ \\
\hline 8 & bullock & $91 / 2$ & 1000 & $23^{*}$ & 0.81 & greyish brown; no lustre \\
\hline 9 & male buffalo & 5 & 500 & $>50$ & 2.13 & light yellowish; lustre \\
\hline 10 & bullock & 8 & 950 & $25^{*}$ & $2.30^{* *}$ & as 9 \\
\hline
\end{tabular}

* and some tiny fractions.

* weight of biggest stone: $0.72,1.04,1.15$, and $0.62 \mathrm{~g}$, respectively. 
The information received together with the samples as to weight and age of the animals is given in Table 2 together with a short description of the samples.

Outwardly the samples were strikingly similar and evidently also similar to those examined by Ranganathan and by Sinha (both loc.cit.). The smaller calculi had the appearance of baroque pearls, including the pearly lustre. The bigger ones seemed to be conglomerates of several such small spheres, kept together and covered by a smooth layer through which the individual spheres were more or less visible. Some of the samples were contaminated with a black material not identified. The stones were hard. When crushed, the outer layer, visibly laminated, was often broken off, leaving a compact core. The weight of the calculi varied from less than $0.05 \mathrm{~g}$ to $1.15 \mathrm{~g}$.

Representative specimens are shown in Fig. 1.

The chemical analysis and the $\mathrm{X}$-ray investigation were carried out by the second author (A. Unmack). The results are given below.

\section{CHEMICAL ANALYSIS}

By qualitative analysis after the method described by Tovborg Jensen \& Thygesen (1941), only $\mathrm{CO}_{3}^{2-}, \mathrm{Ca}^{2+}$, and $\mathrm{Mg}^{2+}$ were found. As $\mathrm{PO}_{4}^{3-}$ was not present in discernible amount, the calculi must be remarkably poor in phosphate compared with human urinary calculi (Prien \& Frondel 1947) and with those of feedlot steers (Cornelius \& Bishop 1961).

By application of a colorimetric micro method a trace of $\mathrm{PO}_{4}^{3-}$ (about $0.5 \%(w / w)$ ) was, however, found in all samples. The content of $\mathrm{Ca}^{2+}$ and $\mathrm{Mg}^{2+}$ was determined by atomic absorption. The water content was determined as the loss at $105^{\circ} \mathrm{C}$. This content (about $1.5 \%(\mathrm{w} / \mathrm{w})$ ) was no bigger than what might be expected in a system of such high dispersion (see later).

From the analytical results it must be concluded that calcium and magnesium are present as carbonates. The results are given in Table 3. The sum of the contents of water, calcium carbonate and magnesium carbonate is never 100. The deficit (probably organic matter) is about $10 \%$ in all cases. The content of organic matter was not determined. 


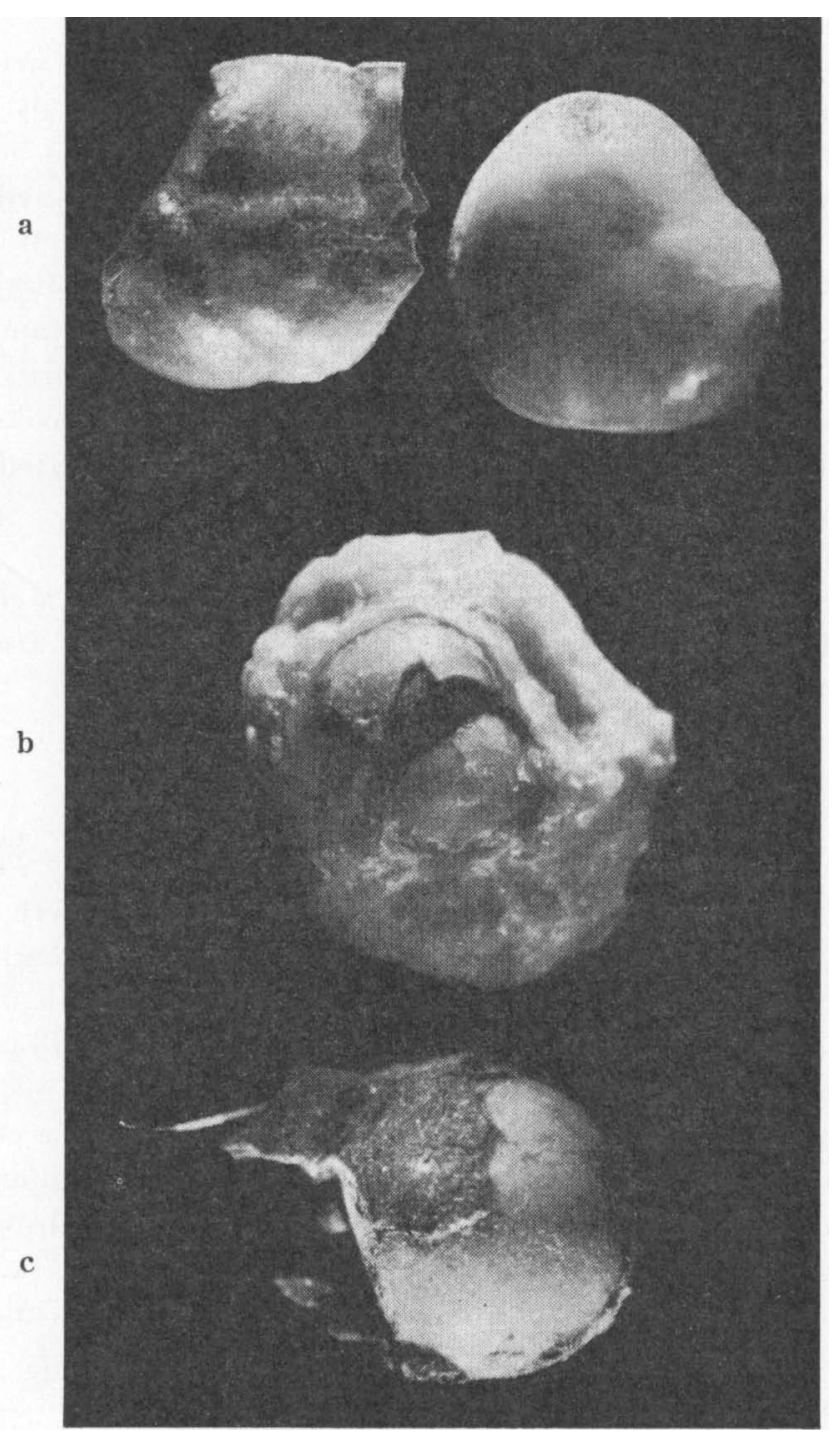

F i g u r e 1. Urinary calculi. a: a lustrous pearl and a piece of shell; b: a partly crushed stone, showing the laminated shell and the inner core consisting of two spheres; c: a lustrous pearl contaminated with dark (unidentified) material. $\times 10$. 
T a b le 3. Chemical composition of the samples.

\begin{tabular}{|c|c|c|c|c|c|c|c|c|c|}
\hline \multirow{2}{*}{$\begin{array}{c}\text { Sample } \\
\text { No. }\end{array}$} & \multicolumn{5}{|c|}{ Percentage $(w / w)$} & \multicolumn{3}{|c|}{ In $100 \mathrm{~g}$ of sample } & \multirow{2}{*}{$\begin{array}{l}\mathrm{Mol} . \% \\
\mathrm{MgCO}_{2}\end{array}$} \\
\hline & $\mathrm{H}_{2} \mathrm{O}$ & $\mathrm{CaCO}_{3}$ & $\mathrm{MgCO}_{3}$ & $\mathrm{PO}_{4}^{2-}$ & total & mol. $\mathrm{CaCO}_{3}$ & $\mathrm{~mol} . \mathrm{MgCO}_{3}$ & $\Sigma \mathrm{mol}$ & \\
\hline 1 & 1.4 & 74.4 & 14.7 & 0.3 & 90.8 & 0.743 & 0.174 & 0.917 & 19.0 \\
\hline 2 & 2.1 & 72.7 & 17.2 & 0.4 & 92.4 & 0.726 & 0.204 & 0.930 & 21.9 \\
\hline 3 & 1.7 & 75.4 & 10.3 & 0.4 & 87.8 & 0.753 & 0.122 & 0.875 & 13.9 \\
\hline 4 & 1.7 & 74.4 & 15.0 & 0.3 & 91.4 & 0.743 & 0.178 & 0.921 & 19.3 \\
\hline 5 & 1.3 & 74.7 & 14.7 & 0.5 & 91.2 & 0.746 & 0.174 & 0.920 & 18.9 \\
\hline 6 & 1.4 & 78.2 & 11.8 & 0.2 & 91.6 & 0.781 & 0.140 & 0.921 & 15.2 \\
\hline 7 & 1.7 & 76.2 & 12.2 & 0.2 & 90.3 & 0.761 & 0.145 & 0.906 & 16.0 \\
\hline 8 & 1.0 & 75.7 & 13.1 & 0.2 & 90.0 & 0.756 & 0.155 & 0.911 & 17.0 \\
\hline 9 & 1.4 & 74.7 & 15.5 & 0.3 & 91.9 & 0.746 & 0.184 & 0.930 & 19.8 \\
\hline 10 & 1.6 & 74.4 & 10.6 & 0.3 & 86.9 & 0.743 & 0.126 & 0.869 & 14.5 \\
\hline
\end{tabular}

In all samples, reactions for oxalic acid, uric acid and ammonium salts were negative.

\section{X-RAY INVESTIGATION}

Chemical analysis has shown that the main constituent of the calculi is calcium carbonate, but of this compound three different crystal forms are known, each of them having its individual solubility. X-ray investigation was therefore undertaken to obtain information on the crystal structure. Powder diagrams were taken of all samples with $\mathrm{Co}-\mathrm{K} \alpha$-radiation ( $\mathrm{Fe}$ filter) in $19 \mathrm{~cm}$ cameras of the Bradley type. In one case diagrams were taken of material from the inner core and the outer shell separately. No difference was seen. All diagrams corresponded to calcite, somewhat modified. All lines were considerably broadened and somewhat displaced towards higher diffraction angles.

The broadening may more or less be due to reduced particle size, but other possible causes exist, for instance an inhomogeneity of the material. If the crystallites to some degree have different composition (cf. p. 417, 1. 15-17), the lattice constants will vary and the lines therefore be unsharp.

The displacement towards higher angles, corresponding to a contraction of the lattice, can be explained by a partial substitution in the lattice of the larger calcium ion by the smaller magnesium ion.

If it is assumed that the only reason for the line broadening is a small particle size, the average dimension of the crystallites can be approximately determined (see for instance Peiser et al. 
1955, p. 413). As Bradley diagrams are not suited for this purpose, diffractometer curves were taken with $\mathrm{Cu}-\mathrm{K} \alpha$-radiation (Ni filter). By means of these curves the breadth of a certain peak at half peak height could be determined. From the difference in the value of this breadth for poorly and for well crystallized material ( $B$ and $b$, respectively) the average particle size may be calculated by means of the formula:

$$
\mathbf{B}-\mathbf{b}=\mathbf{K} \lambda /(\mathbf{t} \cos \theta),
$$

where $\lambda$ is the wave length used, $\theta$ is the diffraction angle, and $K$ is a constant approximately equal to 1 . When $B-b$ is given in radians, the formula gives $t$, the particle dimension, in $\AA$.

The measurements gave the following approximate values: $\begin{array}{lllllllllll}\text { samples Nos. } & 1 & 2 & 3 & 4 & 5 & 6 & 7 & 8 & 9 & 10\end{array}$

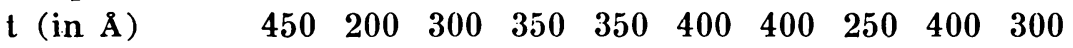

The diffractometer curves were also used for a determination of the lattice spacing, $d$, of the strongest calcite line ( $d$ is given by the formula $\mathrm{d}=\lambda j(2 \sin \theta))$.

In pure calcite $d$ for this line is $3.035 \AA$. In magnesian calcites the spacing is smaller, as already mentioned. The decrease, $\Delta d$, is very nearly proportional to the magnesium content as seen from Fig. 2 where $\Delta \mathrm{d}$ is plotted against mol. $\% \mathrm{MgCO}_{3}(\mathrm{x})$ deter-

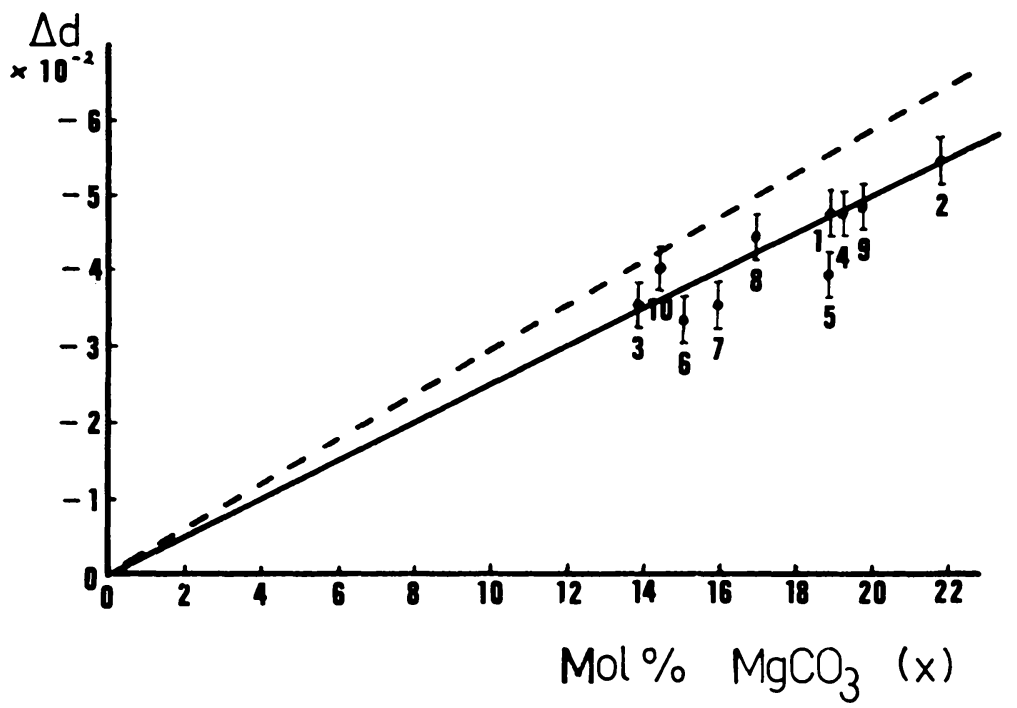

Figure 2. Experimental correlation between $x$ and $\Delta d$ for the $\mathbf{1 0}$ samples compared with Goldsmith's curve (-..-.-). The estimated uncertainty of $\Delta \mathrm{d}$ is indicated. 
mined by atomic absorption. Because the material is poorly crystallized, the peak is low and broad, and the uncertainty in $2 \theta$, and therefore also in $\Delta \mathrm{d}$ is considerable.

The correlation between $\Delta \mathrm{d}$ and $\mathrm{x}$ in magnesian calcites has been investigated by Goldsmith et al. $(1955,1961)$. They examined synthetic, homogeneous and well crystallized specimens, and their measurements are consequently more accurate than ours. They find significantly larger decrease in $d$ with increasing magnesium content than we do. Considerations which we shall not discuss here make it reasonable that the decrease in $d$ with increasing $\mathrm{x}$ will be smaller and more fluctuating in poorly crystallized and probably inhomogeneous material than in the perfectly crystalline, homogeneous material used by Goldsmith et al. $(1955,1961)$.

We know that our samples are poorly crystallized and it is more than likely that a sample formed over a longer period should not be homogeneous.

\section{DISCUSSION}

It might be of interest to compare the present results with those of the older Indian investigations in which carbonate stones were found, especially with those of Ranganathan (1931a), mostly from Andhra Pradesh. As already remarked all older results (given in Table 1) have been recalculated to a common scale (per cent Ca etc.). Even after this recalculation the values are not strictly comparable, because it has not always been stated whether the percentages are given in relation to the original sample or to the dried material. For carbonate stones the water content is always small, so for this type of stones the general

T a b l e 4. Mol. per cent $\mathrm{MgCO}_{3}$ in carbonate stones.

\begin{tabular}{lcccr}
\hline \multirow{2}{*}{ Authors } & $\begin{array}{c}\text { Number of } \\
\text { samples }\end{array}$ & \multicolumn{3}{c}{ Mol. per cent $\mathrm{MgCO}_{3}$ in carbonate } \\
\cline { 3 - 5 } & & min. & max. & average \\
\hline $\begin{array}{l}\text { Ranganathan (1931a) } \\
\text { Sinha (1952) }\end{array}$ & $\begin{array}{c}23 \\
\text { Mohanty (1963) }\end{array}$ & 6.3 & 23.3 & 13.2 \\
Ranjhan et al. (1965) & 10 & 18.4 & 27.4 & 23.9 \\
Kataria \& Rao (1969) & 6 & 0.4 & 5.5 & 3.1 \\
Rao \& Unmack (1973) & 10 & 14.5 & 21.9 & 17.5 \\
\hline
\end{tabular}


picture will not be much influenced by this uncertainty. Moreover, this uncertainty is of no importance when the values of mol. $\% \mathrm{MgCO}_{3}$ in the magnesian calcites are compared. As not only the average values, but also the lower and upper limits found are of interest, the mol. $\% \mathrm{MgCO}_{3}$ has been calculated for each individual sample (Table 4).

It is interesting to note that in the 40 years between the investigation of Ranganathan and the present one the character of the calculi found in cattle of Andhra Pradesh has not changed, and that the same type of concrements has been found in North and in Central India.

The remarkable constancy in constitution exhibited by carbonate calculi may possibly give some indication of the conditions which prevailed in the urine from which they were deposited. The authors are at present investigating the precipitation of magnesian calcites from aqueous solutions in the hope of finding the limits of composition of solutions resembling normal bovine urine between which highly dispersed magnesian calcites with about 14 to $22 \mathrm{~mol} . \% \mathrm{MgCO}_{3}$, devoid of phosphate, will precipitate at body temperature. A solution of this problem would be of immense interest, but so far we have not been able to solve it. In our experiments phosphate free solutions invariably precipitated pure and well crystallized Mg-free calcite. When phosphate was added in concentrations likely to be present in bovine urine colloidal hydroxyapatite was formed.

The composition of the urine from the animals who had produced the samples was not known. In future it will be attempted to collect samples of urine simultaneously with the removal of the calculi.

\section{ACKNOWLEDGEMENTS}

The authors are greatly indebted to G. Espersen, Professor of Surgery, Royal Veterinary and Agricultural University, Copenhagen, for his encouragement to this investigation, to $A$. Tovborg Jensen, Professor of Chemistry at the same institution, for the permission to use the facilities of his laboratory, and for his many valuable suggestions, and to Rama Rao, Veterinary Surgeon, Repallo, Guntur District, Andhra Pradesh, India, for collecting the materials required for this study. 


\section{REFERENCES}

Chakrabarti, R. L., B. Dutt \& B. S. Kaushal: Ecological studies of urolithiasis in domestic ruminants. a) Survey of the natural indicence in relation to pathoanatomy. Sci. Rep. Div. Pathol. Ind. vet. Res. Inst., Izatnagar, U.P., India. 1970. Project code no. 203.

Cornelius, C. E. \& J.A. Bishop: Ruminant urolithiasis III. Comparative studies on the structure of urinary concretions in several species. J. Urol. (Baltimore) 1961, 85, 842-848.

Connell, R., F. Whiting \& S. A. Forman: Silica urolithiasis in beef cattle I. Observation on its occurrence. Canad. J. comp. Med. 1959, 23, 41-46.

Forman, S. A. \& F. Sauer: Some changes in the urine of sheep fed a hay high in silica. Canad. J. Animal Sci. 1962, 42, 9-17.

Forman, S. A., F. Sauer, D. B. Laughland \& W. N. Davidson: Volume and acidity of urine of sheep fed hay rich in silica, and effect of dietary salt additions. Nature (Lond.) 1958, 182, 1385.

Forman, S. A., F. Whiting \& R. Connell: Silica urolithiasis in beef cattle III. Chemical and physical composition of uroliths. Canad. J. comp. Med. 1959, 23, 157-162.

Gehres, R. F. \& S. Raymond: A new chemical approach to the dissolution of urinary calculi. J. Urol. (Baltimore) 1951, 65, 471483.

Goldsmith, J. R., D. L. Graf \& O. I. Joensuu: The occurrence of magnesium calcites in nature. Geochim. Cosmochim. Acta 1955, 7, 212-230.

Goldsmith, J.R., D. L. Graf \& H. C. Heard: Lattice constants of the calcium magnesium carbonates. Amer. Mineralogist 1961, 46, 453-457.

Kataria, R. S. \& U. R. K. Rao: Chemical composition of some bovine nephroliths. Indian vet. J. 1969, 46, 848-854.

Meyer, J.: Sur la dissolution des calculs vésicaux et le traitement consécutif aux opérations sur la vessie et l'urètre. (On the dissolution of bladder stones and on the treatment after operations on vesica and urethra). Presse méd. 1925, 12, 3-12.

Meyer, J.: Om urinvejskonkrementers opløselighed. (On the dissolution of urinary concrements). Thesis. Copenhagen 1927, $260 \mathrm{pp}$.

Meyer, J.: Uber die Ausfällung von Sedimenten und die Bildung von Konkrementen in den Harnwegen. (On the precipitation of sediments and the formation of concrements in the urinary tract). Z. klin. Med. 1929, 111, 612-687.

Mohanty, G. C.: Studies on the pathology of urinary system of bovines with special reference to urolithiasis. Agra Univ. J. Res. (Science) 1963, 12 (III), 179-180.

Mulvaney, W. P.: A new solvent for certain urinary calcifications. J. Urol. (Baltimore) 1959, 82, 546-548.

Mulvaney, W. P.: The clinical use of Renacidin in urinary calcifications. J. Urol. (Baltimore) 1960, 84, 206-212. 
Peiser, H. S., H. P. Rooksby \& A. C. J. Wilson: X-ray diffraction by polycrystalline materials. London Inst. Physics 1955. John Wright \& Sons, Ltd., Stonebridge Press, Bristol.

Prien, E. L. \& C. Frondel: Studies on urolithiasis I. The composition of urinary calculi. J. Urol. (Baltimore) 1947, 57, 949-994.

Ranganathan, S.: Chemical composition of urinary calculi in cattle. Indian J. med. Res. 1931a, 19, 935-973.

Ranganathan, S.: Research on "stones", X. Cattle stones. Indian J. med. Res. 1931b, 19, 49-50.

Ranjhan, S. E., G. C. Mohanty \& S. K. Talapatra: Hard water and urinary calculi. Indian vet. J. 1965, 42, 182-185.

Rao, N. R., S. V. Rao \& D. F. Walker: Indwelling catheter for ruptured bladder and urethral obstruction in ox. Indian vet. J. 1972, 49, 825-837.

Sinha, S. K.: Urolithiasis in bovines in Bihar. Indian vet. J. 1952, 28, 453.

Tovborg Jensen, A.\& J. E. Thygesen: Kemisk undersøgelse af urinvejskonkrementer. (Chemical analysis of urinary concrements). Ugeskr. Læg. 1941, 30, 970-976.

Whiting, F., R. Connell \& S. A. Forman: Silica urolithiasis in beef cattle II. The incidence on different rations and on range. Canad. J. comp. Med. 1958, 22, 332-337.

\section{SAMMENDRAG}

Urolithiasis hos kvæg i Andhra Pradesh.

Blæresten fra de tre tyre, seks stude og en bøffeltyr fra Guntur distriktet er blevet undersøgt. Ved kemisk analyse fandtes kun carbonat, calcium, magnesium og et spor af fosfat. Røntgenunders $\varnothing$ gelse viste, at alle prøverne bestod af magnesiumholdig calcit med et magnesiumindhold mellem 14,5 og 21,9 atomprocent. St $\varnothing r r e l s e n$ af krystalitterne varierede fra ca. 200 til $400 \AA$.

(Received September 20, 1972).

Reprints may be requested from: Department of Surgery, Royal Veterinary and Agricultural University, Bülowsvej 13, DK-1870 Copenhagen V, Denmark. 